\section{Світлана Орлик,}

доктор історичних наук, професор, професор кафедри історії, археологіï, інформаційної та архівної справи

e-mail:

svitlana.orlik@gmail.com ORCID: 0000-0002-6280-9273 Researcher ID: C-1033-2019 Центральноукраїнський національний технічний університет, пр. Університетський, 8, м. Кропивницький, Україна, 25006.

\section{Анна Лузанова,}

здобувач ступеня магістра 3 «Інформаційної, бібліотечної та архівної справи»

ORCID: 0000-0003-1405-3798 Центральноукраїнський національний технічний університет, пр. Університетський, 8, м. Кропивницький, Україна, 25006.

\section{Svitlana Orlyk,}

$\mathrm{PhD}$ hab. (History), Professor, Professor of Department of History, Archeology, Informational and Archival Affairs e-mail:

svitlana.orlik@gmail.com ORCID:0000-0002-6280-9273 Researcher ID: C-1033-2019

Central Ukrainian National Technical University, 8, Prospekt Universytetsky, Kropyvnytskyi, Ukraine, 25006.

\section{Anna Luzanova,}

Applicant for a Master's Degree in «Information, Library and Archival Affairs»

ORCID: 0000-0003-1405-3798

Central Ukrainian National Technical University, 8, Prospekt Universytetsky, Kropyvnytskyi, Ukraine, 25006.

\title{
ABSTRACT
}

In the last ten years of rapid development, there has been an increase in informatization of the society, and the Internet has become not only an integral part of a social life, as the main source of information, but also a necessary tool for science investigations. The problem of using Web-resources in scientific, in particular, 
numismatic researches, has been actively studied in recent decades. It is clear that such an important information resource as the Internet contains a diverse information from various areas of research, including numismatics. This information is contained in various domestic and foreign sites. There are a huge number of numismatic sites today, which differ qualitatively in their information capabilities. On the one hand, it is part of amateur websites, and on the other - the websites of numismatic societies, numismatic shops and auctions, including online. Numismatic pages are even available on social networks.

The sites of Ukrainian museums, which were investigated by us, contain photo reports, announcements, and photo materials from the field-oriented exhibitions that are regularly organized for visitors. Some sites place a "Exhibit of the Week» section on their pages, which often displays rare medals, banknotes or orders. Regarding the official website of the British Museum, it can be concluded that it contains significant information potential for researchers of the history of money circulation around the world, and the page of the Department of Coins and Medals is the most valuable for researchers of numismatics and bonistics. Thanks to the digitized information available on the museum's online page, we have the opportunity to immerse ourselves in the study of numismatic collections without leaving home.

In general, high-quality official websites of museum institutions have a significant information potential for scientists and facilitate the promotion of both the museum institutions themselves and the activities of museums, including numismatics.

Keywords: WEB-resources, Official sites of Museums, numismatics, National Museum of the History of Ukraine, Odessa Archeological Museum, Kharkiv Historical Museum, British Museum, the popularization of museum activities.

Постановка проблеми. В останні десятиріччя стрімкого розвитку набула інформатизація суспільства, а мережа Інтернет стала невід'ємною частиною не лише суспільного життя як основне джерело інформації, а й обов'язковим інструментом 
для наукових досліджень. Адже «поширення сучасних інформаційних технологій вплинуло на всі сфери суспільного життя, стало глобальним фактором цивілізаційного розвитку» (Головацька, 2009: 23). Учені, користуючись Web-ресурсами знаходять необхідну літературу, вивчають результати наукових досліджень своїх колег з усього світу. Онлайн музеї в наш час займають важливе місце, особливо в період світових катаклізмів. Завдяки онлайн музеям науковці мають можливість проводити дослідження, а студенти та просто бажаючі мають можливість поповнювати свої знання, навіть не виходячи 3 дому. Важливо, що на онлайн сторінці музею $є$ зображення, повна характеристика, детальний опис монет із різних колекцій, завдяки чому можна здійснювати наукові дослідження. У статті для порівняльного дослідження взято офіційні веб-сайти Національного музею історії України, Одеського археологічного музею НАН України, Харківського історичного музею імені М. Ф. Сумцова та Британського музею.

Аналіз досліджень і публікацій. Проблема використання Web-peсурсів в наукових, зокрема нумізматичних дослідженнях, активно вивчається протягом останніх десятиліть (Коцур, 2013: 3-8; Лузанова, 2020: 144146; Нечитайло, 2019: 77-87; Орлик, 2013: 129-133; Орлик, Орлик, 2019: 5-27; Хромова, 2013: 203-207; Швець, 2015: 15-18; Шевчук, 2019: 320-335; Шпортун, 2016: 174-179: 23-26 та ін.), a самі Web-ресурси стали важливою частиною джерельної бази нумізматичних досліджень (Kotsur, 2016: 7-9; Mielczarek, Orlyk, 2019: 33-39; Myzgin, 2017; Orlyk, 2016: 93-97; Бойко-Гагарін, 2017; Крижанівський, 2019: 67-76; Кулешов, 2018: 43-51; Мойсеєнко, 2018: 32-42; Орлик, 2017: 37-74; Орлик, БойкоГагарін, 2017: 143-164; Орлик, 2018: 81-93 та ін.).

Метою статті $\epsilon$ аналіз інформаційного потенціалу офіційних Web-pесурсів музейних установ та роль цих сайтів у популяризації музеїв та напрямків їхньої діяльності, у тому числі й нумізматики. 
Виклад основного матеріалу. Зрозуміло, що такий важливий інформаційний ресурс як Інтернет, містить різнопланову інформацію 3 різних напрямків наукових досліджень, у тому числі й з нумізматики. Ця інформація міститься на різноманітних вітчизняних та зарубіжних сайтах, адже «на сьогодні існує величезна кількість нумізматичних сайтів, які якісно різняться своїми інформаційними можливостями. 3 одного боку, це частина любительських сайтів, а 3 іншого, - сайти нумізматичних товариств, нумізматичних магазинів та аукціонів, у тому числі й online. Нумізматичні сторінки є навіть у соціальних мережах... Саме тому пошукові системи не завжди дають списки сайтів, корисних для наукових досліджень» (Орлик, 2013: 129).

Необхідно зазначити, що в суспільстві сформувалися два розуміння нумізматики. Одне - «наукове, яке розглядає нумізматику як спеціальну галузь історичної науки, яка входить до комплексу історичних наук, спирається на свої специфічні джерела (перш за все монети і монетні скарби), має свій специфічний понятійно-категоріальний апарат і термінологію, здатну вирішувати складні питання, особливо в галузі економіки минулого» (Потин, 1986: 74).

Друге розуміння нумізматики «склалося у сфері музейній та колекціонерській. У цьому сенсі нумізматика - галузь історичних знань, що має справу не тільки з монетами, а й 3 іншими монетовидними предметами (медалями, жетонами, орденами, знаками), а також товаро-грошима і паперовими грошима» (Потин, 1986: 74).

Зупинимося більш детально на музейних Web-pecypcax, на яких представлені різні нумізматичні джерела та нумізматичні дослідження. Попередньо зазначимо, що нумізматичні джерела вчені поділяють на дві групи: основні нумізматичні джерела, що $є$ одночасно нумізматичними пам'ятниками (монети, монетні скарби, предмети пов'язані 3 виробництвом монет і їх обігом), і допоміжні нумізматичні джерела (так звані примітивні гроші, або товаро-гроші; медалі, жетони, нагородні знаки; печатки; паперові грошові знаки та 
безперечно письмові джерела), тобто ті історичні джерела, які дозволяють доповнити наші знання й уточнити висновки, отримані при дослідженні основних нумізматичних джерел (Потин, 1986: 72). У мережі Інтернет зустрічаються практично всі види згаданих вище нумізматичних джерел, проте найбільш репрезентовані «перші два джерела - власне монети та інформація про монетні знахідки» (Орлик, 2013: 129).

У наш час, особливо в період світових катаклізмів, онлайн музеї займають важливе місце. Завдяки онлайн музеям науковці мають можливість проводити дослідження, а студенти та просто бажаючі мають можливість поповнювати свої знання, навіть не виходячи 3 дому. Важливо, що на онлайн сторінці музею має бути зображення, повна характеристика, детальний опис монет із різних колекцій, завдяки чому можна здійснювати наукові дослідження.

Відповідно до сучасного уявлення музейних маркетологів та PR-менеджерів, офіційна Інтернет-сторінка або сайт музею повинні містити інформацію для відвідувача із зазначенням локалізації та назви музею, опис того, якими колекціями володіє музей та які на поточний момент наявні послуги відвідувачу. Інформація з офіційного сайту часто дублюється повністю або частково на сторінках музею в соціальних мережах. У маркетинговому дослідженні музейної діяльності А. Бойко-Гагарін наводить скрін-шот з офіційного сайту Національного музею історії України в якості прикладу анонсу виставки «Ярослав Мудрий: два образи (до 1000-річчя княжіння в Києві)» із зображенням залученої до виставки сучасної обігової монети України номіналом 2 гривні 2018 року iз зображенням портрета великого князя Ярослава Мудрого (Бойко-Гагарін, 2020: 104-105).

Зупинимося детальніше на аналізі нумізматичних матеріалів, розміщених на WEB-ресурсах деяких вітчизняних та зарубіжних музеїв. Для порівняльного дослідження візьмемо офіційні веб-сайти Національного музею історії України (далі - НМІУ), Одеського археологічного музею НАН України (далі - ОАМ), Харківського історичного музею імені 
М. Ф. Сумцова (далі - XIM) та Британського музею (далі - БМ).

Найбільша в Україні нумізматична колекція зберігається в НМІУ. На офіційній сторінці цього провідного музею України розміщено інформацію про історію створення музею, його колекції та основні послуги, які команда закладу пропонує відвідувачу (Національний музей історії України. Офіційна сторінка). Показово, що сторінка виконана в сучасному стилі iз зручною навігацією та наповнена якісним контекстом, зокрема дизайнерськими фото, креативними рішеннями тощо. Так, з метою запросити відвідувача обрати екскурсію, на головній сторінці гортаються фотоколажі з предметами, про які екскурсовод розповість відвідувачеві, серед них пропонується також замовити екскурсію 3 історії грошового обігу (Національний музей історії України. Офіційна сторінка. Виставка 3 історії грошового обігу), під час показу якої демонструється златник великого князя Володимира Святославича й наводиться інформація про виставку та іiі розташування. Певні застороги викликає теза про те, що серед репрезентованих на цій виставці «близько 3 тисяч грошових монет та банкнот, які охоплюють період від III тис. до н.е., коли в племенах трипільської культури виникає регулярний обмін товарами, до грошової системи незалежної України» (Національний музей історії України. Офіційна сторінка. Виставка 3 історії грошового обігу). Адже товарообмінні операції часів трипільської культури та грошовий обіг є явно не зовсім суміжними поняттями.

На сторінці музею, у підрозділі «Фонди національного музею історії України», міститься функціональний напрямок «Нумізматика» (Національний музей історії України. Офіційна сторінка. Фонди національного музею історії України). На Інтернет-сторінці розміщено інформацію, підготовлену завідувачкою сектору нумізматики, фалеристики, медальєрики та боністики 3. Зразюк про основні фондові групи зберігання iз зазначенням історії формування впродовж XIX-XX ст. нумізматичної колекції, яка сьогодні «налічує близько 120 тис. 
монет, медалей, орденів, паперових грошей, знаків та значків» (Національний музей історії України. Офіційна сторінка. Фондові колекції. Нумізматика), надано фото деяких одиниць зберігання та цілком слушно наголошено, що «нумізматична колекція НMIУ є важливим науковим джерелом вивчення історії України та її грошового обігу від найдавніших часів до сьогодення» (Національний музей історії України. Офіційна сторінка. Фондові колекції. Нумізматика). Сторінка «Нумізматика» має вісім функціональних напрямків «Монети Греції, Риму та Сходу», «Від давньої Русі до 1917», «Монети СРСР та пострадянські», «Монети Західної Європи та ін.», «Паперові грошові знаки», «Медальєрика», «Фалеристика», «Сфрагістика». На сторінці кожного 3 цих функціональних напрямків міститься короткий опис відповідного підрозділу колекції та наводяться фотографії монет.

Зупинимося детальніше на сторінці кожного функціонального напрямку. Так, сторінка «Монети Греції, Риму та Сходу» інформує про те, що «колекція НМІУ монет Давньої Греції, Риму, Візантії та Сходу є однією з найбільших на пострадянському просторі й налічує понад 10 тис. од. зб.» (Національний музей історії України. Офіційна сторінка. Фондові колекції. Нумізматика. Монети Греції, Риму та Сходу). На даній Інтернет-сторінці, окрім короткої характеристики цього підрозділу нумізматичної колекції музею, містяться й зображення деяких монет, проте без детального опису, що практично унеможливлює їх використання в наукових дослідженнях без безпосередньої роботи в цьому фонді НМІУ. Для якої, до речі, необхідно отримати відповідний дозвіл від керівництва музею, який при попередній директорці Т. Сосновській був досить обмеженим навіть для вчених, а не лише для дослідників-початківців. Сподіваємось, що 3 приходом на посаду генерального директора доктора історичних наук $Ф$. Андрощука ситуація зміниться в позитивний бік і НМІУ стане доступним для наукових досліджень, а не закритою установою як це, на жаль, мало місце протягом лютого 2015 - березня 2020 рр. 
Сторінка функціонального напрямку «Від давньої Русі до 1917», при переході на яку спостерігаємо дещо іншу назву «Монети Київської Русі, Червоної Русі (львівські монети), Київського князівства (Володимира Ольгердовича), удільних князівств північно-східної Русі, московського царства, російської імперії» (Національний музей історії України. Офіційна сторінка. Фондові колекції. Нумізматика. Монети Київської Русі, Червоної Русі (львівські монети), Київського князівства (Володимира Ольгердовича), удільних князівств північно-східної Русі, Московського царства, Російської імперіï). На сторінці цього функціонального напряму офіційного сайту НМІУ, як i на попередній, містяться зображення деяких монет, зокрема аверсу златника Володимира Великого; аверсу та реверсу срібляника I типу, а також аверсу срібляника III типу цього правителя; аверсу та реверсу срібляника Святополка; зображення монетних гривень київського, новгородського та чернігівського типів; аверсу та реверсу монети (денарія?) київського князя Володимира Ольгердовича; аверсу та реверсу гроша галицько-руського Людвіга Угорського та ін.

На Інтернет-сторінці функціонального напрямку «Монети СРСР та пострадянські» вказується, що до цієї групи зберігання НМІУ віднесені й монети України. Зокрема, «зберігається унікальна підбірка перших обігових монет незалежної України, карбованих на Луганському верстатобудівному заводі (1992-1996). Це пробні екземпляри 1992 р. номіналом 10, 25 та 50 коп.; 2 коп. 1993 р.; 2, 10, 25 та 50 коп. 1994 р. (лише пробний варіант); 50 коп. та 1 гривня 1995 р.; всі номінали 1996 р. та пробна монета 50 шагів 1992 р.» (Національний музей історії України. Офіційна сторінка. Фондові колекції. Нумізматика. Монети СРСР та пострадянських країн).

При переході за функціональним напрямком «Монети Західної Європи та ін.» відкривається сторінка «Монети Західної Свропи, Америки та Австралії». Дана складова нумізматичної колекції систематизована за історико- 
географічним принципом, вона складається 3 колекційної та скарбової частин і охоплює близько 40000 одиниць зберігання, у тому числі й «понад 50 знахідок XIV ст. - поч. XX ст., виявлених під час земляних робіт або у складі скарбів» (Національний музей історії України. Офіційна сторінка. Фондові колекції. Нумізматика. Монети Західної Свропи, Америки та Австралії). Щодо зображення монет на сторінці цього функціонального напряму офіційного сайту НМІУ, то не можна залишити поза увагою, фотографії донативів ${ }^{*}$ королів Речі Посполитої, зокрема, аверсу і реверсу 10-ти дукатів Сигізмунда III Вази, карбованої у м. Гданськ 1614 року, 3-х дукатів Яна II Казимира, карбованої у м. Торунь 1659 року, а також зображення скарбу західноєвропейських і московських монет XV-XVII ст., знайденого у 2000 р. на березі р. Ворона, поблизу с. Лелюхівка, Новосанжарського району Полтавської області.

Допоміжні нумізматичні джерела, репрезентовані на сторінках функціональних напрямків «Паперові грошові знаки», «Медальєрика», «Фалеристика» та «Сфрагістика», за структурою наповнення аналогічні проаналізованим вище сторінкам функціональних напрямків розділу «Нумізматика».

Аналіз сторінки «Нумізматика» на офіційному сайті HМIУ та іï функціональних напрямків вказує на наявні методологічні помилки при структуруванні колекції, які, ймовірно, були закладені через радянські ідеологеми та на відповідне спотворення історичного минулого після повернення колекції з евакуації після Другої світової війни. Так, зокрема, до розділу колекції античних монет безпідставно віднесені монети Візантійської імперії та Сходу. А функціональний напрямок «Від давньої Русі до 1917», котрий при переході на його сторінку отримує дещо іншу назву «Монети Київської Русі, Червоної Русі (львівські монети),

\footnotetext{
Донатива - нумізматична пам'ятка, що випускалася для подарунків привілейованим особам, зокрема в Польщі в 1582 - 1685 рр. на монетних дворах Гданська і Торуні... Ознакою, що наближає донативу до монети, $є$ те, що вона карбувалася відповідно до кратної ваги дуката (від 11ㄹㄹ до 20), що й було визначено на деяких з них. (Зварич, 1980: 68).
} 
Київського князівства (Володимира Ольгердовича), удільних князівств північно-східної Русі, московського царства, російської імперії», має не лише граматичні помилки в назві, зокрема написання назв держав з малої літери, а й суттєві методологічні огріхи. Це, перш за все, поєднання, як і в попередньому функціональному напрямку, непоєднуваних понять. Дана складова нумізматичної колекції НМІУ сформована в контексті російської імперської та радянської ідеологем про спадкоємність державності від Русі до Російської імперії і, відповідно, руської та російської нумізматики. Незважаючи на трансформацію назви сторінки з «Від давньої Русі до 1917» на «Монети Київської Русі, Червоної Русі (львівські монети), Київського князівства (Володимира Ольгердовича), удільних князівств північно-східної Русі, московського царства, російської імперії», наявність у розділі колекції монет Московського царства та Російської імперії лише підтверджують це. Досить примітним у цьому плані $є$ те, що певні емісії українських земель доби середньовіччя i, які б мали входити до даного підрозділу нумізматичного зібрання НМІУ, віднесені до підрозділу «Монети Греції, Риму та Сходу». Так, зокрема, на сторінці даного функціонального напряму офіційного сайту НМІУ вказується, що в «колекції зберігаються також два скарби, важливі для вивчення історії грошового обігу в Україні в XIV ст. - із с. Василиці Черкаської обл., знайдений у 1925 р., та із с. Борщів Київської обл., виявлений у 1948 р. У складі цих монетних депозитів серед монет Золотої Орди знаходилися невідомі нумізматичній науці монети - т. зв. «київські» наслідування дензі Джанібека, що, ймовірно, карбувалися в Києві в 1354-1363 рр., та наслідування ординських монет хана Мухамеда, яке дослідники ототожнюють 3 карбуванням Новгород-Сіверського князівства часів правління Дмитра-Корибута (1381-1404). Дослідження й атрибуція цих монет відкрили для науки нові центри монетного виробництва на території України в XIV ст.» (Національний музей історії України. Офіційна сторінка. Фондові колекції. Нумізматика. Монети Греції, Риму та Сходу). А про групу зберігання «Монети України, РСФРР, СРСР та пострадянських 
країн» необхідно зазначити, що якщо попередні підрозділи нумізматичного зібрання Національного музею історії України структурувалися в повоєнний період, то додавання монет України до групи зберігання радянських і пострадянських монет - це нонсенс. На наше переконання, співробітники музею, хоча б до 30-річчя Незалежності Україні мають усунути дані негаразди, а не відбутися організацією чергової виставки у «кращих радянських традиціях». Зрозуміло, що дану проблему практично нереально розв'язати лише силами сектору нумізматики, фалеристики, медальєрики та боністики через надзвичайну забюрократизованість фондової роботи, проте вона $\epsilon$ вкрай необхідною для надання принципу історизму як важливої методологічної парадигми найбільшій в Україні нумізматичній колекції - колекції НМІУ.

Можемо стверджувати, що офіційний Інтернет-сайт НМIУ має значний інформаційний потенціал у плані популяризації роботи музею, але, на жаль, мінімальний для науковців.

ОАМ володіє другою за величиною колекцію нумізматики в Україні. В музеї нумізматична колекція представлена не лише окремими екземплярами монет по всіх залах експозиції, а й зібранням «Золота кладова», яка $\epsilon$ перлиною серед усіх залів, доступних відвідувачам музею.

У розділі сайту ОАМ НАН України «Структура музею» міститься покликання на сторінку відділу нумізматики і торевтики. Дана сторінка розподілена за такими функціональними напрямками: антична нумізматика (Греція, Рим); нумізматика Західної Свропи; медалі, ордени, знаки, сфрагістика; російська нумізматика.

Щодо інформаційного потенціалу вказаних напрямків аналізованої сторінки сайту ОАМ НАН України, то необхідно зазначити, що всі вони мають окремі сторінки не поділені на функціональні напрямки i містять коротку інформацію стосовно сторінки та відповідні ілюстрації. Так, зокрема, на сторінці «Антична нумізматика» зазначається, що колекція давньогрецьких монет ОАМ НАН України «охоплює 
тисячолітній період - 3 VI століття до н.е. по V століття н.е.» (Одеський археологічний музей. Офіційна сторінка. Відділ нумізматики. Антична нумізматика (Греція, Рим)). На цьому функціональному напрямку сайту вказується, що у фондах музею «представлені відомі декадрахми м. Сіракузи, монети великих правителів давнини - царя Персії Дарія, македонських царів Пилипа II і Олександра Великого, держави Селевкідів, Понтійського царства, Парфії, фракійських царів, Карфагена i античних полісів Північного Причорномор'я» (Одеський археологічний музей. Офіційна сторінка. Відділ нумізматики. Антична нумізматика (Греція, Рим)). Також на даній сторінці офіційного сайту ОАМ розміщено 6 ілюстрацій. Розробниками сайту була порушена хронологія монетних випусків під час розміщення зображень, адже ілюстрації розміщені таким чином: аверси соліда імператора Валентиніана I, денарій імператора Септімія Севера, золотий статер царя Лісімаха, ольвійський срібний статер, тетрадрахма Афін, а також аверси i реверси трьох електрових монет кізікінів із орловського скарбу.

Щодо нумізматики Західної Свропи, то на відповідній сторінці офіційного сайту ОАМ вказується, що даний розділ музейної колекції нараховує більше чотирьох тисяч одиниць зберігання, це монети, які карбувалися на теренах Західної Свропи протягом середньовіччя та нового часу. Стосовно формування даної колекції вказується, що «початок зібрання відноситься до моменту створення Мюнцкабінету Одеського Товариства історії та старожитностей, велику роль у створенні якого зіграв засновник Товариства М. М. Мурзакевич» (Одеський археологічний музей. Офіційна сторінка. Відділ нумізматики. Нумізматика Західної Свропи).

Певні методологічні зауваги є щодо сторінки «Російська нумізматика». Так, зокрема, на сайті вказується, що в ОАМ НАН України «зберігаються також монети, час випуску яких охоплює кінець X - середину XX століття. Це монети домонгольскої Русі, платіжні зливки безмонетного періоду 
(гривні), монети періоду феодальної роздробленості Київської Русі, епохи Російської централізованої держави, імператорського періоду i монети радянського чекану» (Одеський археологічний музей. Офіційна сторінка. Відділ нумізматики). Як бачимо, короткий опис цієї частини музейної колекції містить ряд методологічних та фактологічних помилок, зокрема, до групи зберігання «Російські монети», безпідставно віднесені монети, які карбувалися до створення держави, у назві якої була офіційно закріплена назва «Росія», а ототожнення монет Київської Русі із російськими взагалі неприпустимо. Ця методологічна помилка характерна для музеїв на пострадянському просторі, й, на жаль, музейники через заформалізованість фондової документації не спішать ії виправляти. Необхідно також зазначити, що сайт не розрахований на дистанційну науково-дослідну роботу, а лише для інформування користувачів та популяризації музею.

Значну за обсягами колекцію нумізматики в Україні зберігає XIM. Перша вкладка офіційного сайту цього музею інформує відвідувача про всі умови здійснення відвідин музею, включаючи детальний опис локації із шляхами досягнення до неї громадським транспортом, графік роботи музею, ціни на квитки, а також перелік послуг. Серед новин на головній сторінці музею розмішено статті співробітників музею, у тому числі й нумізматичного спрямування. Наприклад, публікацію О. Желтобородової про наявну в нумізматичному зібранні музею зливку-гривні Київського типу межі XI-XII століття, доповнено детальною історією побутування цих грошових знаків, а також надано якісні фото даної одиниці зберігання (Харківський історичний музей ім. М. Ф. Сумцова. Офіційна сторінка. Інші статті. Гривні-зливки з колекції музею). Іншою статтею в зазначеному розділі привертає увагу допис Юлії Стаднік про великоформатні монети у вигляді металевих кованих плит, що були поширеними у XVII-XVIII столітті. Але варто зауважити, що 3 високим ступенем імовірності 
представлені в замітці музейні предмети можуть бути новоробленими монетами XIX століття або неавтентичними копіями, виготовленими спеціально для музейного експонування за відсутності автентичних подібних зразків дуже цікавих для відвідувача монет (Харківський історичний музей ім. М. Ф. Сумцова. Офіційна сторінка. Інші статті. Монети-плати XVIII ст.). Значну увагу наповнювачами офіційної інтернет-сторінки музею приділено опису всіх наявних колекцій, в тому числі й нумізматичної. У вкладці надано детальний опис структури нумізматичної колекції, яка «налічує майже 25000 монет, відображає економічний розвиток i товарно-грошовий обіг майже 50 країн світу», та наголошується, що нумізматична колекція музею формувалася «складалася протягом багатьох років, була започаткована на поч. $\mathrm{XX}$ ст. i продовжує поповнюватися новими надходженнями. За типами монет вона досить різноманітна: до iii складу входять знаки оплати домонетного періоду, монети регулярного державного карбування, монети ювілейні, пам'ятні, пробні, новороби, монети спецвипусків, великовагові монети-плати тощо. Також у колекції зберігаються двадцять вісім скарбів різного наповнення» (Харківський історичний музей ім. М. Ф. Сумцова. Офіційна сторінка. Колекція. Нумізматика). Серед загальної інформації про дане зібрання міститься опис деяких монет різних історичних періодів та емітентів, дублюється із згаданих вище статей інформація про монетно-вагові зливки гривні та великоформатні мідні монети. На даній сторінці сайту досить інформативним для дослідників нумізматики та історії грошового обігу є контент щодо скарбів, які зберігаються в музеї: «Скарби, у тому числі монетні, $є$ найцікавішою комплексною знахідкою і здебільшого несуть в собі історичну та археологічну цінність. Переважна частина скарбів колекції ХІМ була знайдена на території Харківської області протягом 50-60-х рр. ХХ ст. До їх складу належать як мідні, так і срібні російські, польські та литовські монети 
періоду XVII-XVIII ст., а також монети 11 ханів Золотої Орди, датовані XIV ст.» (Харківський історичний музей ім. М. Ф. Сумцова. Офіційна сторінка. Колекція. Нумізматика).

На жаль, на офіційному сайті ХІМу немає можливості для дистанційного ознайомлення з нумізматичною колекцією, як до речі, із іншими колекціями цього музею, тому для науковців він може бути корисним лише для отримання попередньої інформації щодо предметів, які зберігаються в XIM, перед безпосередньою роботою у фондах.

Стосовно зарубіжних, зокрема європейських музейних установ, зупинимося на аналізі офіційного сайту Британського музею (далі - БМ.), який, безперечно, містить значний інформаційний потенціал для дослідників історії грошового обігу в усьому світі (Лузанова, 2020: 144-146). Найбільш цінним для дослідників нумізматики і боністики на даному сайті є сторінка Кафедри монет і медалей (Department of Coins and Medals). Сайт є зручним для науковців, адже передбачає дистанційну роботу 3 джерелами, що традиційно для європейських музейних та архівних установ. Щоб переглядати предмети із колекції Монети та медалі в навчальному кабінеті, потрібно заповнити заявку на навчальний кабінет та надіслати iii електронною поштою: coins@britishmuseum.org. (Department of Coins and Medals).

Проведемо порівняння офіційних веб-сайтів НМІУ, ОАМ НАН України, ХІМ ім. М. Ф. Сумцова та БМ.

Усі вищезазначені сайти, за винятком НМІУ, є багатомовними, однак перелік підтримуваних мов доволі незначний $(2-3)$. Також слід зауважити, що переклад на сайті http://museum.kh.ua $€$ неповним: по суті для іноземних користувачів зроблена окрема сторінка сайту з перекладом англійською, тоді як інформація на інших сторінках, головне меню, логотип 3 назвою тощо завжди залишаються українською мовою. 
На трьох із чотирьох досліджуваних сайтів (крім ОАМ) присутні посилання на соціальні мережі, що дозволяє їм застосовувати заходи SMM-маркетингу (Social Media Marketing), спрямованих на пізнаваність бренду, роботу 3 цільовою аудиторією, підвищення рівня лояльності та налаштування зворотного зв'язку з користувачами.

Як видно з базового url-префіксу, українські веб-сайти музеїв використовують незахищений протокол передачі даних http. Коли підключення до сайту незахищене, браузери, особливо від Google, будуть показувати користувачам повідомлення про те, що на сайті незахищене з'єднання і що вони можуть стати жертвою шахраїв. Існує також ризик підміни інформації на самому сайті (наприклад, підміни реклами власника на рекламу зловмисника). Зазначені фактори можуть значно знизити конверсію, адже мало хто захоче залишати дані на сайті, з якого їх можуть викрасти. Захищене 3'єднання є обов'язковим для тих сайтів, де користувачі вводять і передають конфіденційну інформацію (особисті дані, деталі доступу, реквізити платіжних карт) - загалом на будьяких сайтах 3 авторизацією, взаємодією 3 платіжними системами, поштовими сервісами. Оскільки на веб-ресурсах українських музеїв немає сервісів реєстрації/авторизації користувачів та будь-яких послуг з продажу послуг/продукції, то для них на сьогоднішній день це необов'язкова умова використання захищеного протоколу https. Разом з тим Google наполегливо рекомендує приділяти більше уваги рівню безпеки сайту та довіри не тільки з боку користувачів, але й пошукової системи.

Офіційний веб-сайт БМ, хоча і не містить сервісів, де користувачі можуть вводити й передавати особисту чи конфіденційну інформацію, проте має безпечне з'єднання, більш високий індекс швидкодії (категорія В - дуже добре), значно кращі показники відвідуваності (основні відвідувачі представники Великобританії (35,4\%), США (22,3\%), Китаю 
(3,5\%), Італії $(3,1 \%)$ (Market intelligence platform), окрему сторінку з детальною картою закладу. На жаль, веб-сайти українських музеїв відсутні в базі даних SimilarWeb, що не дозволяє нам аналізувати географію їх відвідувачів.

Час завантаження головної сторінки на https://www.britishmuseum.org/ дещо більший за українські (трохи більше 2 секунд на десктоп-пристроях), однак тут слід враховувати значно більший обсяг представленого на ній контенту. Для надання комерційних послуг функціонує окремий веб-сайт https://www.britishmuseumshoponline.org/, те саме стосується іншомовної версії сайту (переклад зроблено лиш китайською мовою) - табл. 1. Сьогодні пошукові системи «звертають увагу на такі показники, як швидкодія сервера, час завантаження сторінок, ефективне кодування зображень, коректне відображення контенту на мобільних пристроях, валідний веб-код та ін.» (В. Крашенінін). Проте, як видно з табл. 1, суттєвим недоліком сайтів українських музеїв $є$ їх низька швидкодія, проблеми з адаптивністю (відображенням на мобільних пристроях), некоректний код, не належним чином налаштований веб-сервер тощо, що не тільки зменшує довіру до них пошукових систем, але й відштовхує відвідувачів, для яких важлива не лише якість контенту, але і юзабіліті, адаптивність, кросбраузерність. Так, згідно 3 даними моніторингового порталу https:/gtmetrix.com ранг досліджуваних вітчизняних сайтів знаходиться в межах F-D (тобто, нижчий за середній), тоді як гарним показником можна вважати В, а відмінним - А. 
Таблицุя 1

\section{Порівняльна характеристика офіційних веб-сайтів Національного музею історії України, Одеського археологічного музею НАН України, Харківського історичного музею імені М. Ф. Сумцова та Британського музею}

\begin{tabular}{|c|c|c|c|c|}
\hline Показник & $\begin{array}{c}\text { Національни } \\
\text { й музей } \\
\text { історії } \\
\text { України } \\
\end{array}$ & $\begin{array}{c}\text { Одеський } \\
\text { археологічний } \\
\text { музей НАН } \\
\text { України } \\
\end{array}$ & $\begin{array}{c}\text { Харківський } \\
\text { історичний музей } \\
\text { iм. М. Ф. Сумцова }\end{array}$ & $\begin{array}{c}\text { The British } \\
\text { Museum }\end{array}$ \\
\hline Сторінка у Вікіпедії & + & + & + & + \\
\hline Кількість мов (назви) & 1 & 3 (ukr, rus, en) & 2 (ukr, en) & $\begin{array}{c}2(\mathrm{en}, \\
\text { chinese)* }\end{array}$ \\
\hline $\begin{array}{l}\text { Переходів на сайт (в } \\
\text { місяць, за даними } \\
\text { Google) }\end{array}$ & 556 & 189 & 906 & 3590 \\
\hline $\begin{array}{l}\text { Індекс швидкодії сайту } \\
\text { (більше - краще)** }\end{array}$ & $F(16 \%)$ & $\mathrm{D}(62 \%)$ & $\mathrm{F}(48 \%)$ & B $(81 \%)$ \\
\hline Підключення сайту & $\begin{array}{c}\text { Безпечне } \\
\text { (захищений } \\
\text { протокол } \\
\text { передачі) }\end{array}$ & $\begin{array}{c}\text { Небезпечне } \\
\text { (незахищений } \\
\text { протокол } \\
\text { передачі) }\end{array}$ & $\begin{array}{c}\text { Небезпечне } \\
\text { (незахищений } \\
\text { протокол } \\
\text { передачі) }\end{array}$ & $\begin{array}{c}\text { Безпечне } \\
\text { (захищени } \\
\text { й протокол } \\
\text { передачі) }\end{array}$ \\
\hline $\begin{array}{l}\text { Авторизація } \\
\text { користувачів }\end{array}$ & 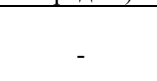 & (2) & - & $+/$ - **** \\
\hline Інтернет-магазин & $-/+* * * *$ & - & - & $+/-* * * *$ \\
\hline Сервіси онлайн-оплати & $-/+* * * *$ & - & - & $+/-* * * *$ \\
\hline $\begin{array}{l}\text { Наявність favicon } \\
\text { (графічний логотип) }\end{array}$ & - & - & + & + \\
\hline Карта музею & - & - & - & + \\
\hline Контактна інформація & + & + & + & + \\
\hline $\begin{array}{l}\text { Посилання на соціальні } \\
\text { мережі }\end{array}$ & $\begin{array}{c}+ \\
\text { (facebook, } \\
\text { youtube, } \\
\text { instagram) }\end{array}$ & - & $\begin{array}{c}+ \\
\text { (facebook, } \\
\text { youtube, } \\
\text { instagram) }\end{array}$ & $\begin{array}{c}+ \\
\text { (facebook, } \\
\text { twitter, } \\
\text { youtube, } \\
\text { instagram) }\end{array}$ \\
\hline
\end{tabular}

\footnotetext{
* функціонує окремий сайт http://britishmuseum.org.cn/

** дані моніторингового порталу https:/gtmetrix.com

*** для сервісів розроблена окрема версія сайту за посиланням https://www.britishmuseumshoponline.org/

**** сервіси реалізовані на сторінці https://nmiu.kontramarka.ua/, яка не відноситься до досліджуваного сайту
} 


\begin{tabular}{|l|c|c|c|c|}
\hline $\begin{array}{l}\text { Наявність сторінки, } \\
\text { присвяченої } \\
\text { нумізматиці }\end{array}$ & + & + & + & + \\
\hline $\begin{array}{l}\text { Час завантаження } \\
\text { сторінки нумізматики } \\
\text { (менше - краще)** }\end{array}$ & $2,9 \mathrm{c}$ & $1,0 \mathrm{c}$ & $1,3 \mathrm{c}$ & $2,1 \mathrm{c}$ \\
\hline
\end{tabular}

Висновки. Аналіз нумізматичних сторінок на офіційних сайтах НМІУ й ОАМ та їхніх функціональних напрямків вказує на ряд методологічних помилок, допущених під час структурування колекції, які, ймовірно, були закладені через радянські ідеологеми та на відповідне спотворення історичного минулого. Перш за все, віднесення до російської нумізматики монет Київської Русі та руських земель в період пізнього середньовіччя та раннього нового часу. Можемо стверджувати, що проаналізовані в статті офіційні Інтернет-сайти ряду українських музеїв мають значний інформаційний потенціал у плані популяризації роботи музею, але, на жаль, мінімальний для науковців. Прикро, що на офіційних сайтах Національного музею історії України, Одеського археологічного музею НАН України та Харківського історичного музею ім. М. Ф. Сумцова немає можливості для дистанційного ознайомлення 3 нумізматичною колекцією, як до речі, з іншими колекціями цих музеїв, тому для науковців дані Інтернет-ресурси можуть бути корисними лише для отримання попередньої інформації щодо предметів, які зберігаються в музейних установах, перед безпосередньою роботою у фондах. Власне, ці музейні Інтернет-ресурси спрямовані, переважно, на популяризацію та PR музейних установ і радше виконують функції зв'язків із громадськістю, а не $є$ базою для наукових досліджень. Водночас офіційний сайт Британського музею зручний для науковців, адже передбачає дистанційну роботу з джерелами, що традиційно для європейських музейних та архівних установ. 
Також необхідно зазначити, що суттєвим недоліком сайтів українських музеїв $є$ їх низька швидкодія, проблеми 3 адаптивністю (відображенням на мобільних пристроях), некоректний код, не належним чином налаштований веб-сервер тощо, що не лише зменшує довіру до них пошукових систем, але й відштовхує відвідувачів, для яких важлива не лише якість контенту, а й юзабіліті, адаптивність, кросбраузерність.

\section{ДЖЕРЕЛА ТА ЛІТЕРАТУРА}

1. Бойко-Гагарін А.С. (2020). Музей, що заробляє. Manual для маркетолога. Київ: Логос. 200 с.

2. Бойко-Гагарін А. (2017). Фальшивомонетництво у Центральній та Східній Свропі в добу Середньовіччя та раннього Нового часу. Київ. 549 с.

3. Головацька I. (2009) Особливості використання Інтернетресурсів бібліотеками Галичини. Вісник Книжкової палати. № 4. C.23-26. URL: http://nbuv.gov.ua/UJRN/vkp_2009_4_10 (Дата звернення: 22.10.2020).

4. Зварич В.В. Нумизматический словарь. Львов: Издательское обьединение «Вища школа». 338 с.

5. Коцур В.П. (2013). Актуальні напрямки та організаційні засади сучасних досліджень середньовічної нумізматики в Україні. Наукові записки з української історії: 3б. наук. cmameй. Вип. 33. Переяслав-Хмельницький. С.3-8.

6. Kotsur V. (2016). Methodological issues of modern numismatic research: materials of «black» archeology and scientific research. Forum Numizmatyczne: Peniadz i mennice. №1. C.7-9.

7. Крашенінін В. У чому полягає технічний SEO аудит сайту? URL: https://cutt.ly/khZ185h.

8. Крижанівський А. (2019). Визначення ступенів рідкісності при складанні каталогу на прикладі монет Галицької Руси XIV-XV ст. Украӥнський нумізматичний щзорічник. Вип. 3. С. 67-76. URL: https://doi.org/10.31470/26166275-2019-3-67-76. 
9. Кулешов С. (2018). Три фальшиві середньовічні західноєвропейські денарії, знайдені в Рівненській області. Український нумізматичний щзорічник. Вип.2. С. 43-51. https://doi.org/10.31470/2616-6275-2018-2-43-51.

10. Лузанова А. (2020). Нумізматика на сайті Британського музею. Історія, археологія, інформаційна, бібліотечна та архівна справа: актуальні проблеми науки та освіти: тези доповідей I Міжнародної наукової конферениії, 13 травня 2020 р. Кропивницький: ЦНТУ. С.144-146

11. Mielczarek, M. and Orlyk, V. (2019). New find of Olbian coins. Tarashcha district, Kyiv region, Ukraine. Східноєвропейський історичний вісник. №13, С. 33-39. doi: https://doi.org/10.24919/2519-058x.13.190763

12. Myzgin K. (2017). Roman Republican Coins and Their Imitations from the Territory of Ukraine and Belarus. Warszawa.

13. Мойсеєнко М. (2018). Хронологія знахідок в Україні срібляників типу IV Володимира Святославича. Украӥнський нумізматичний щорічник. Вип.2. С.32-42.

14. Нечитайло В.В. (2019). Інформаційний потенціал Інтернет-ресурсів у вивченні проблем грошового обігу України-Гетьманщини. Соціум. Документ. Комунікаиія: збірник наукових статей. Серія «Історичні науки». Вип. 7. С. 77-87.

15. Орлик B.M. (2013). Інформаційний потенціал WEBресурсів у нумізматичних дослідженнях (на прикладі монет держав Хрестоносців). Матеріали наукової конференції 3 міжнародною участю «Архівознавчі та джерелознавчі галузі знань: проблеми взаємодіі на сучасному етапі». м. Київ, 14 берез. 2013 р., Київ, 2013. С. 129-133.

16. Орлик В.М. (2017). Топографія знахідок в Україні монет держави Тевтонського ордену в Пруссії та іiі Лівонського відділення (зведені відомості по областях). Украӥнський нумізматичний щерічник. Вип.1. 2017 С.37-74.

17. Орлик В.М., Орлик С.В. (2019). Теоретико-методологічні та джерелознавчі проблеми економічної історії України. 
Універсум історії та археології. Том. 2 (27). Вип 2. С. 5-27. doi $10.15421 / 26190201$
18. Орлик
C.B.,
Бойко-Гагарін
A.C.
(2017).

Фальшивомонетництво в Україні в роки Першої світової війни. Украйнський нумізматичний щорічник. № 1. С.143-164.

19. Орлик В. (2018). До питання ідентифікації монет Банату Северин із зображенням чоловічої фігури та хреста у щиті під короною. Украйнський нумізматичний щорічник. Вип.2. С. 8193. URL: https://doi.org/10.31470/2616-6275-2018-2-81-93 (Дата звернення: 22.10.2020).

20. Orlyk V. (2016). A Coin Hoard of Pre-Reform Shillings of the Grand Master Michael Küchmeister von Sternberg Found in Chernihivschyna. Acta Archaeologica Lodziensia. №62. P. 93-97.

21. Потин В.М. (1986). Введение в нумизматику. Труды Государственного Ордена Ленина Эрмитажа. Ленинград: Искусство. Т. 26. С.69-160.

22. Хромова I. (2013). Нумізматика в музейних Інтернетресурсах України. Спеціальні історичні дисципліни: питання теорії та методики : 3б. наук. пр. Ч. 21: Електронні інформаційні ресурси. С. 203-207.

23. Швець О. (2015). Використання інформаційних ресурсів у нумізматичних дослідженнях. Тези доповідей III Міжнародної науково-практичної конференції «Актуальні проблеми нумізматики в системі допоміжних історичних дисииплін», 5-6 листопада 2015 р. Кіровоград-Київ-ПереяславХмельницький, 2015. С.15-18.

24. Шевчук О. (2019). Інформаційні можливості сайту Національного Банку України в дослідженні проблем історії грошового обігу в Україні. Соціум. Документ. Комунікація. Серія: Історичні науки. Вип.8. С. 320-335. DOI: 10.31470/25187600-2019-8-320-335.

25. Шпортун О. (2016). Нумізматичні веб-сайти України. Forum Numizmatyczne, Pieniadz I Mennice Studia I Materialy. № 1. Bialystok. C. 174-179. 


\section{Інтернет-ресурси}

26. Department of Coins and Medals. URL: https://cutt.ly/9hZlxjn.

27. Львівський історичний музей. Офіційна сторінка. URL: https://cutt.ly/XhZlvVV.
28. Market
intelligence
platform.
URL:

https://www.similarweb.com.

29. Музей грошей Національного Банку України. Офіційна сторінка. URL: https://museum.bank.gov.ua/museum/.

30. Національний музей історії України. Офіційна сторінка. URL: https://nmiu.org/.

31. Національний музей історії України. Офіційна сторінка. Виставка 3 історії грошового обігу. URL: https://cutt.ly/FhZlmM9.

32. Національний музей історії України. Офіційна сторінка. Фонди національного музею історії України. URL: https://cutt.ly/xhZlWTo.

33. Національний музей історії України. Офіційна сторінка. Фондові колекції. Нумізматика. URL: https:/cutt.ly/MhZlELH.

34. Національний музей історії України. Офіційна сторінка. Фондові колекції. Нумізматика. Монети Греції, Риму та Сходу. URL: https://cutt.ly/8hZlR8f.

35. Національний музей історії України. Офіційна сторінка. Фондові колекції. Нумізматика. Монети Київської Русі, Червоної Русі (львівські монети), Київського князівства (Володимира Ольгердовича), удільних князівств північносхідної Русі, Московського царства, Російської імперії. URL: https://cutt.ly/0hZlYkx.

36. Національний музей історії України. Офіційна сторінка. Фондові колекції. Нумізматика. Монети СРСР та пострадянських країн. URL: https://cutt.ly/nhZlUxn.

37. Національний музей історії України. Офіційна сторінка. Фондові колекції. Нумізматика. Монети Західної Європи, Америки та Австралії. URL: https://cutt.ly/LhZlIIM. 
38. Одеський археологічний музей. Офіційна сторінка. URL: http://www.archaeology.odessa.ua/.

39. Одеський археологічний музей. Офіційна сторінка. Відділ нумізматики. URL: https://cutt.ly/IhZlPlb.

40. Одеський археологічний музей. Офіційна сторінка. Відділ нумізматики. Антична нумізматика (Греція, Рим) URL: https://cutt.ly/9hZ1SZy.

41. Одеський археологічний музей. Офіційна сторінка. Відділ нумізматики. Нумізматика Західної Європи. URL: https://cutt.ly/NhZlGaP.

42. Одеський археологічний музей. Офіційна сторінка. Відділ нумізматики. Російська нумізматика.

URL: https://cutt.ly/khZlJSt.

43. Харківський історичний музей ім. М.Ф. Сумцова. Офіційна сторінка. URL: http://museum.kh.ua/.

44. Харківський історичний музей ім. М.Ф. Сумцова. Офіційна сторінка. Колекції. Нумізматика. URL: https://cutt.ly/ehZIXr4GTmetrix. Website Speed and Performance Optimization. URL: https://gtmetrix.com.

\section{REFERENCES}

1. Boyko-Haharin, A.S. (2020). Muzey, shcho zaroblyaye. Manual dlya marketoloha [Earning museum. Manual for the marketer]. Kyiv: Lohos. [in Ukrainian].

2. Boiko-Haharin, A. (2017). Falshyvomonetnytstvo $u$ Tsentralnii ta Skhidnii Yevropi v dobu Serednovichchia ta rannoho Novoho chasu [Counterfeiting in Central and Eastern Europe in the Middle Ages and Early Modern Times]. Kyiv. [in Ukrainian].

3. Holovatska, I. (2009) Osoblyvosti vykorystannia Internetresursiv bibliotekamy Halychyny[Features of the use of Internet resources by libraries in Galicia]. Visnyk Knyzhkovoi palaty Bulletin of the Book Chamber, 4. 23-26. [in Ukrainian].

4. Zvarych V.V. (1980) Numizmaticheskiy slovar'. [Numismatic Dictionary]. Lvov. [in Russian].

5. Kotsur, V.P. (2013). Aktualni napriamy ta orhanizatsiini 
zasady suchasnykh doslidzhen serednovichnoi numizmatyky $v$ Ukraini. [Current trends and organizational principles of modern studies of medieval numismatics in Ukraine]. Naukovi zapysky z ukrainskoi istorii - The scientifical notes of the Ukrainian history. (33). 3-8. [in Ukrainian].

6. Kotsur, V. (2016). Methodological issues of modern numismatic research: materials of «black» archeology and scientific research. Forum Numizmatyczne: Peniadz i mennice, 1. 7-9. [in English].

7. Krasheninin, V. U chomu polyahaye tekhnichnyy SEO audyt saytu? [What is a technical SEO audit of the site?]. Retrieved from https://cutt.ly/khZ185h [in Ukrainian].

8. Kryzhanivsky, A. (2019). Vyznachennya stupeniv ridkisnosti pry skladanni katalohu na prykladi monet Halyts'koyi Rusy XIV$\mathrm{XV}$ st. [Determination of the degree of rarity in the compilation of the catalog on the example of coins of Galician Rus' in XIV-XV centuries]. Ukrayins'kyy numizmatychnyy shchorichnyk - The Ukrainian Numismatic Annual, (3), 67-76. Retrieved from https://doi.org/10.31470/2616-6275-2019-3-67-76 [in Ukrainian].

9. Kuleshov, S. (2018). Try falshyvi serednovichni zakhidnoievropeiski denarii, znaideni v Rivnenskii oblasti [Three fake western european deniers find in Rivne region]. Ukrainskyi numizmatychnyi shchorichnyk - The Ukrainian Numismatic Annual, (2), 43-51. Retrieved from https://cutt.ly/6hZzxUX [in Ukrainian].

10. Luzanova, A. (2020). Numizmatyka na sayti Brytans'koho muzeyu []. Istoriya, arkheolohiya, informatsiyna, bibliotechna ta arkhivna sprava: aktual'ni problemy nauky ta osvity. Mizhnarodnoyi naukovoyi konferentsiyi, 13 travnya 2020 r. Kropyvnyts'kyy: TsNTU. 144-146. [in Ukrainian].

11. Mielczarek, M. and Orlyk, V. (2019). New find of Olbian coins. Tarashcha district, Kyiv region, Ukraine. Skhidnoyevropeys'kyy istorychnyy visnyk- Eastern European Historical Bulletin, 13, 33-39. DOI: https://doi.org/10.24919/2519058x.13.190763 [in English]. 
12. Myzgin, K. (2017). Roman Republican Coins and Their Imitations from the Territory of Ukraine and Belarus. Warszawa. [in English].

13. Moiseenko, N. (2018). Khronolohiya znakhidok v Ukrayini sriblyanykiv typu IV Volodymyra Svyatoslavycha [Chronology of the finds of the srebreniks of Vladimir's Svyatoslavich type IV]. Ukrainskyi numizmatychnyi shchorichnyk - The Ukrainian Numismatic Annual. (2). 32-42. [in Ukrainian].

14. Nechytailo, V.V. (2019). Informatsiinyi potentsial Internetresursiv u vyvchenni problem hroshovoho obihu Ukrainy-Hetmanshchyny [Information potential of Internet resources in studying the problems of money circulation of UkraineHetmanate]. Sotsium. Document. Communication. - Sotsium. Dokument. Komunikatsiia: zbirnyk naukovykh statei. Seriia «Istorychni nauky». (7). 77-87. [in Ukrainian].

15. Orlyk, V.M. (2013). Informatsiinyi potentsial WEB-resursiv u numizmatychnykh doslidzhenniakh (na prykladi monet derzhav Khrestonostsiv) [Information potential of WEB-resources in numismatic research (on the example of coins of the Crusaders)]. Materialy naukovoi konferentsii z mizhnarodnoiu uchastiu "Arkhivoznavchi ta dzhereloznavchi haluzi znan: problemy vzaiemodii na suchasnomu etapi», 14 bereznia 2013 r., m. Kyiv. 129-133. [in Ukrainian].

16. Orlyk, V.M. (2017). Topohrafiia znakhidok v Ukraini monet derzhavy Tevtonskoho ordenu $\mathrm{v}$ Prussii ta yii Livonskoho viddilennia (zvedeni vidomosti po oblastiakh) [Topography of finds in Ukraine of coins of the Teutonic Order in Prussia and its Livonian branch (summary information by region)]. Ukrainskyi numizmatychnyi shchorichnyk - The Ukrainian Numismatic Annual. (1). 37-74. [in Ukrainian].

17. Orlyk, V. M. \& Orlyk, S. V. (2019) Teoretykometodolohichni ta dzhereloznavchi problemy ekonomichnoi istorii Ukrainy [Theoretical-methodological and source problems of economic history of Ukraine]. Universum istorii ta arkheolohii Universum of history and archeology. 2 (27). 2, 5-27. [in Ukrainian]. 
18. Orlyk, S. V. \& Boiko-Haharin, A. S. (2017). Falshyvomonetnytstvo v Ukraini v roky Pershoi svitovoi viiny [Money counterfeiting in Ukraine during the WWI]. Ukrainskyi numizmatychnyi shchorichnyk - The Ukrainian Numismatic Annual. (1). 143-164. [in Ukrainian].

19. Orlyk, V. (2018). Do pytannia identyfikatsii monet Banatu Severyn iz zobrazhenniam cholovichoi fihury ta khresta u shchyti pid koronoiu [To the issue of the identification of the coins of the Banate of Severin with the image of the man's figure and a cross in the shield under the crown]. The Ukrainskyi numizmatychnyi shchorichnyk - The Ukrainian Numismatic Annual. (2). 81-93. Retrieved from https://doi.org/10.31470/2616-6275-2018-2-81-93 [in Ukrainian].

20. Orlyk, V. (2016). A Coin Hoard of Pre-Reform Shillings of the Grand Master Michael Küchmeister von Sternberg Found in Chernihivschyna. Acta Archaeologica Lodziensia. 62. 93-97 [in English].

21. Potin, V.M. (1986). Vvedenie v numizmatiku [Introduction to numismatics]. Trudy Gosudarstvennogo Ordena Lenina Ermitazha-Proceedings of the State Order of Lenin Hermitage. Leningrad: Iskusstvo. (26). 69-160 [in Russian].

22. Khromova, I. (2013). Numizmatyka v muzeinykh Internetresursakh Ukrainy [Numismatics in museum Internet resources of Ukraine]. Spetsialni istorychni dystsypliny: pytannia teorii ta metodyky - Special historical disciplines: questions of theory and methodology. (21). 203-207 [in Ukrainian].

23. Shvets, O. (2015). Vykorystannia informatsiinykh resursiv u numizmatychnykh doslidzhenniakh [Use of information resources in numismatic research]. Tezy dopovidei III Mizhnarodnoi naukovo-praktychnoi konferentsii «Aktualni problemy numizmatyky $v$ systemi dopomizhnykh istorychnykh dystsyplin», 5-6 lystopada 2015 r. Kirovohrad-Kyiv-Pereiaslav-Khmelnytskyi. 15-18 [in Ukrainian].

24. Shevchuk, O. (2019). Informatsiini mozhlyvosti saitu Natsionalnoho Banku Ukrainy $v$ doslidzhenni problem istorii 
hroshovoho obihu $v$ Ukraini. [Informational possibilities of the National Bank of Ukraine Web -site in research of the history problems of monetary circulation in Ukraine]. Sotsium. Dokument. Komunikatsiia. - Society. Document. Communication. (8). 320-335 DOI: 10.31470/2518-7600-2019-8-320-335. [in Ukrainian].

25. Shportun, O. (2016). Numizmatychni veb-sayty Ukrayiny [Numismatic websites of Ukraine]. Forum Numizmatyczne, Pieniadz I Mennice Studia I Materialy. 1. 174-179 [in Ukrainian].

\section{АНОТАЦІЯ}

В останні десятиріччя стрімкого розвитку набула інформатизачія суспільства, а мережа Інтернет стала невід 'ємною частиною не лише суспільного життя як основне джерело інформачіï, а й обов'язковим інструментом для наукових досліджень. Проблема використання Web-ресурсів у наукових, зокрема нумізматичних дослідженнях, активно вивчається протягом останніх десятиліть. Зрозуміло, шо такий важливий інформащійний ресурс як Інтернет, містить різнопланову інформацію з різних напрямків наукових досліджень, у тому числі й з нумізматики. Ця інформація міститься на різноманітних вітчизняних та зарубіжних caŭmax.

На жаль, украйнські музейні Інтернет-ресурси спрямовані переважно на популяризацію $\mathrm{ma} P R$ музейних установ і радше виконують функиії зв'язків із громадськістю, а не є базою для наукових досліджень. Водночас офічійний сайт Британського музею є зручним для науковиів, адже передбачає дистанційну роботу з джерелами, щзо традиційно для європейських музейних та архівних установ.

Також необхідно зазначити, щуо суттєвим недоліком сайтів украӥнських музеїв є їх низька швидкодія, проблеми з адаптивністю (відображенням на мобільних пристроях), некоректний код, не належним чином налаштований вебсервер тощо, щзо не лише зменшує довіру до них пошукових систем, але й відштовхує відвідувачів, для яких важлива не 
лише якість контенту, а i юзабіліті, адаптивність, кросбраузерність.

Ключові слова: WEB-ресурси, офіційні сайти музеїв, нумізматика, Національний музей історії Украӥни, Одеський археологічний музей, Харківський історичний музей, Британський музей, популяризація музейної діяльності.

\section{АННОТАЦИЯ}

В последние десятилетия стремительное развитие приобрела информатизация общества, а сеть Интернет стала неотьемлемой частью не только общественной жизни, как основной источник информации, но и обязательным инструментом для научных исследований. Проблема использования Wеb-ресурсов в научных, в частности, нумизматических исследованиях, активно изучается в течение последних десятилетий. Понятно, что такой важный информационныи ресурс как Интернет, содержит разноплановую информацию по различнылм направлениям научных исследований, в том числе и по нумизматике. Эта информачия содержится на различных отечественных $и$ зарубежных сайтах.

К сожалению, украинские музейные Интернет-ресурсы направлень преимущцественно на популяризацию $u$ PR музейных учреждений, и скорее выполняют функции связей с общественностью, а не базы для научных исследований. В то же время официальный сайт Британского музея является удобным для ученых, ведь предполагает удаленную работу с источниками, что кстати, является традиционным для европейских музейных и архивных учреждений.

Также необходимо отметить, что сущеественным недостатком сайтов украинских музеев является их низкое быстродействие, проблемь с адаптивностью (отображением на мобильных устройствах), некорректный код, не должным образом настроен веб-сервер, не только уменьшает доверие к ним поисковых систем, но и отталкивает посетителей, для 
которьх важно не только качество контента, но и юзабилити, адаптивность, кроссбраузерность.

Ключевые слова: WEB-ресурсы, официальные сайты музеев, нумизматика, Национальный музей истории Украиньы, Одесский археологический музей, Харьковский исторический музей, Британский музей, популяризаџия музейной деятельности. 